\title{
Carving a Diplomatic Niche?: The April 1956 Soviet Visit to Britain
}

\author{
SIMON MILES
}

\begin{abstract}
Nikita Khrushchev and Nikolai Bulganin's visit to Britain in April 1956 was the first by the new Soviet leadership to a Western bloc country after Josef Stalin's death. It presented British policy-makers with a unique opportunity for insight and discussion. However, British self-deception regarding their scope for independent action as well as excessive focus on events in the Middle East hampered efforts to build a rapport with Khrushchev and Bulganin. This analysis explores the planning and conduct of what turned out to be a fruitless diplomatic initiative. The visit illustrates British and Soviet policy at the time, as well as Britain's already clear position as the junior partner in the Anglo-American "special relationship" on the eve of Suez.
\end{abstract}

The visit of First Secretary of the Communist Party of the Soviet Union Nikita Khrushchev and Premier Nikolai Bulganin to London from 18 to 27 April 1956 presented British leaders with a unique opportunity. At the time, Britain's international commitments outpaced its resources, it struggled to adapt to the emergence of nuclear weapons as the currency of international power, and public diplomacy gained increased relevance in the Cold War because of this global "balance of terror". British policy-makers saw the Soviet visit - the first bilateral visit by a Soviet leader to a Western country after the death of Josef Stalin in March 1953 - as an opportunity to ameliorate both Britain's relationship with the Soviet Union and the country's standing in the Western alliance. In this respect, British policy-makers were naïve, chasing the ghosts of Britain's past. ${ }^{1}$

Although frequently mentioned by historians, the 1956 Soviet visit is analysed inadequately. A recent exception is Mark B. Smith's "Peaceful Coexistence at All Costs", which addresses the visit within the context of increased transnational ties. ${ }^{2}$ The limited historiographical treatment of the visit itself overlooks the episode as a valuable Cold War case study. As Sir Anthony Eden, the prime minister at the time, cautioned in his memoirs, 
"events were never seen in isolation at the time, but were constantly entangled with a dozen other problems which were vexing us simultaneously. None of them can be understood in isolation from the others". ${ }^{3}$ Studying the April 1956 Soviet visit to Britain offers a means of assessing several important Cold War themes: Britain's struggle to define its role in the 1950s; the evolving nature of the Anglo-American "special relationship"; the post-Stalinist foreign policy of the Soviet Union in practice; and the opportunities and pitfalls of the state visit as a diplomatic device.

Initially, British policy-makers decided to invite the Soviet leadership to visit Britain as a means of cultivating positive relations between the two Powers' leaders. After Stalin's death, Eden's predecessor, Sir Winston Churchill, entertained considerable hope that this would be possible. ${ }^{4}$ Many Soviets policies thereafter engendered such hopes in Western leaders as the new Soviet leadership facilitated a truce in the Korean War, eased traffic restrictions between West Berlin and West Germany through the German Democratic Republic, renounced past claims to Turkish territory, and cancelled the planned eviction of the British and American embassies from the immediate vicinity of the Kremlin. ${ }^{5}$ The conclusion of the Austrian State Treaty on 15 May 1955 in particular gave impetus to British policy-makers. Sir William Hayter, the British ambassador in Moscow, believed the treaty indicated a broad Soviet willingness to negotiate, and Soviet acceptance of Austrian neutrality offered a potential model that Western leaders hoped to apply in other areas of Cold War tension. ${ }^{6}$

The Foreign Office did not share the enthusiasm for a summit with the Soviets. As foreign secretary under Churchill, Eden had opposed a potential visit. His opposition, however, stemmed from a concern that Churchill would use summit diplomacy to further delay his retirement and thereby Eden's accession to the premiership. ${ }^{7}$ These objections evaporated when Eden became prime minister - he adopted Churchill's plan to invite Soviet leaders to Britain as his own. The prime minister's Foreign Office advisors, however, remained sceptical that this initiative would produce any significant results. ${ }^{8}$ Despite this doubt, the British delegation led by Eden extended an invitation to their Soviet counterparts at the 1955 Geneva Conference. After the Soviets' agreeable behaviour at Geneva, Eden and the Foreign Office hoped that the invitation would precipitate further positive discussions. ${ }^{?}$

Initially planning to host a good-will visit, British policy-makers sought to "bring Bulganin and Khrushchev face-to-face with Western reality": the Soviet leaders would see British cities, industry, and military installations first-hand. ${ }^{10}$ Policy-makers, however, dramatically reassessed the nature of the visit after Khrushchev and Bulganin made scathing remarks regarding Britain's colonial past and its abuses of indigenous populations whilst touring Asia. ${ }^{11}$ The Foreign Office recommended cancellation, arguing that the visit could no longer fulfil "its original purpose of promoting closer and better 
relations between the two countries". Casting the derogatory speeches as "a deliberate campaign of misrepresentation", many in Eden's Cabinet argued that Britain would seem weak if it did not respond to the Soviets' offensive statements. ${ }^{12}$

Not willing to squander this perceived opportunity, Eden instead seized upon the comments as justification to shift the nature of the visit toward highlevel Anglo-Soviet negotiations on pressing Cold War issues. ${ }^{13}$ This focus appealed most to him because it ultimately better served British interests than cancellation. ${ }^{14}$ Eden made the final decision regarding the visit authoritatively, consulting only the foreign secretary, Selwyn Lloyd. ${ }^{15}$ In large part, Eden's confidence in his own abilities as a negotiator shaped his hubristic decision. 1954 had constituted an annus mirabilis for Eden as foreign secretary. He facilitated the creation of the Western European Union, fostered the inclusion of West Germany in the North Atlantic Treaty Organisation (NATO), and achieved considerable success at the 1954 Geneva Conference. ${ }^{16}$ In light of these successes, Eden "thought that he had a talent for solving intransigent problems". ${ }^{17}$ In 1956, no problem could be considered more intransigent than the hostility between the Soviet Union and the West, nor any in which the rewards of success were so great. Confident in his own skills as a negotiator, Eden changed Britain's objectives drastically from the initial plans for a good-will visit. In all the aforementioned cases of personal success, however, Eden had worked in concert with American policy-makers. His naïve attempt at unilateral Cold War diplomacy in April 1956 would prove to be another matter.

Britain's limited understanding of the political structure of the postStalin Soviet Union hampered planning for Anglo-Soviet negotiations. The British had struggled to comprehend the possibility of a power struggle in the Kremlin following Stalin's death, as the Soviet Union had seemed so monolithic beforehand. ${ }^{18}$ By the time of the visit, through their global network of intelligence-sharing agreements, British policy-makers had access to no small amount of evidence that Khrushchev controlled the Kremlin directly. Moreover, for example, a Japanese parliamentary delegation noted that during their Asian trip, Khrushchev did all of the substantive talking whilst Bulganin remained silent. ${ }^{19}$ During Khrushchev and Bulganin's crucial 1955 visit to Yugoslavia to repair bilateral relations, their hosts treated Khrushchev as the pre-eminent Soviet leader. ${ }^{20}$ The joint communiqué identified Khrushchev as the head of the Soviet delegation, equal in standing to the Yugoslav leader, Marshal Josip Broz Tito. ${ }^{21}$ At the 1955 Geneva Summit, American attendees identified Khrushchev as the principal decision-maker in the Soviet leadership. ${ }^{22}$

The Foreign Office rejected these conclusions and continued to debate who truly led the Soviet Union; in fact, the Foreign Office only reached a definite conclusion during the April 1956 visit itself. ${ }^{23}$ Personalities and perception remained crucial in shaping London's interpretation. The British 
doubted that a man as uneducated as Khrushchev could be of great importance. ${ }^{24}$ Harold Macmillan, Selwyn Lloyd's predecessor, opined that Bulganin "looks like a Radical-Socialist Mayor of a French industrial town" and wondered how Khrushchev, "this fat, vulgar man, with his pig eyes and ceaseless flow of talk, [could] really be the head ... of all these millions of people and this vast country?" 25 Reflecting an "Ornamentalist" approach, British policy-makers assessing Khrushchev's importance dismissed him primarily because of his peasant origins and coarse manners. ${ }^{26}$ He seemed to Hayter "rumbustious, impetuous, loquacious, free wheeling, [and] alarmingly ignorant of foreign affairs". ${ }^{27}$ Accordingly, the ambassador dissuaded Eden and the Foreign Office from discussing official matters pertaining to the visit with him. ${ }^{28}$ Underestimating Khrushchev seriously impaired Britain's ability to understand the Soviet Union and the motivations behind its policies. In light of Britain's admittedly limited understanding of the Soviet leadership, Eden miscalculated in deciding to undertake serious bilateral negotiations without sufficient information regarding the two Soviet leaders, motivated by naïveté and over-confidence in his skills as a negotiator.

Once Eden decided that the Soviet visit would proceed, the British needed to formulate their own objectives for the visit in its new form. ${ }^{29}$ The plan drawn up by the Foreign Office called first for an assessment of Anglo-Soviet relations, followed by a broad discussion of world affairs. ${ }^{30}$ Policy-makers identified three areas of discord for discussion - the Middle East, Germany, and disarmament - anticipating to make substantive progress in reducing tensions over each of these major areas of conflict. ${ }^{31}$ The agenda's simplicity would hopefully prevent the Soviets from preparing a rehearsed policy platform. Despite this stated aim, the Eden government prepared inflexible positions on the three core issues of discussion - precisely the attitude British policy-makers actively worked to prevent the Soviets from adopting, and one that they knew would hamper any potential breakthrough. ${ }^{32}$ When asked about its goals for the visit by the United States, the Eden government predicted progress on major international issues through these bilateral negotiations and expected to gain a better understanding of the Soviet Union than other Western countries through direct and extensive contact at the highest level. ${ }^{33}$

In looking at Soviet objectives and motivations for their British visit, Khrushchev initially opposed the idea of a summit because he feared that the West would take advantage of the turmoil caused by Stalin's death to extract concessions. His outlook changed over time, however, and he embraced direct negotiation as the best way to overcome foreign and domestic opponents. His 1955 visit to Yugoslavia and the resultant Soviet-Yugoslav rapprochement proved crucial to his increased faith in personal diplomacy. ${ }^{34}$ Along with this growing willingness to negotiate, the Soviets' confidence in Eden rose: they considered him "a progressive figure" capable of improving relations because of his resignation over appeasement in $1938 .{ }^{35}$ When 
asked by a journalist if he would like to visit Britain, Khrushchev responded enthusiastically in the affirmative. ${ }^{36}$

Building upon earlier impressions of Eden as a viable partner, the 1955 Geneva summit underscored the Soviet belief that British leaders were open to negotiations, unlike their American counterparts. Khrushchev believed that Secretary of State John Foster Dulles - "a man lacking in common sense [and] intoxicated and paralyzed by hatred" - controlled American foreign policy. ${ }^{37} \mathrm{He}$ considered discussions with the British delegation more fruitful, and he respected Eden's visibly active role in formulating British foreign policy. However, precipitated by the death of Stalin, the visit to Britain, like the tour of Asia, was part of a Soviet diplomatic revolution. ${ }^{38}$ Eden identified this openness and the opportunity it presented for policy innovation in London. As Evelyn Shuckburgh, one of Eden's private secretaries at the Foreign Office, recounted after the 1955 Geneva Summit:

He said that in his own private view the Russians were looking for ... someone to hold their hands a little. They could not expect anything from America, and they saw that the French were no use, so they were looking to us. I said this was a gratifying thought - just the sort of role we should like to play - to which he replied that perhaps it was only wishful thinking. ${ }^{39}$

Soviet willingness to negotiate with Eden, however, did not match Britain's ambitious objectives for the visit. Whilst the Soviets certainly looked forward to ameliorate the bilateral relationship, and perhaps reach some minor agreements, they were far from prepared to make the kind of far-reaching accords that Eden envisioned. Thus, the British misjudged this attitude and focused their preparations on serious negotiations of little interest to their Soviet counterparts. ${ }^{40}$

British preparations for the Soviet visit, particularly Eden's, emphasised negotiations as the visit's focal point. ${ }^{41}$ These discussions centred on the main areas of Anglo-Soviet discord identified by British policy-makers: the Middle East, Germany, and disarmament. As a state visit, the Soviet trip presented opportunities away from the negotiating table to improve bilateral relations. To examine the visit as both an illustration of trends in the Cold War and a diplomatic device, the Soviets' disastrous dinner with the Labour Party and British attempts at intelligence gathering and showcasing the country's strength and modernity are instructive.

British policy-makers in 1956 focused chiefly on the Middle East, whose issues wholly preoccupied the prime minister as the Soviet visit approached. Eden viewed the turbulence in the region as his own personal challenge and surrounded himself with a small group who agreed about its primacy and his capacity to secure a breakthrough in regional tensions. ${ }^{42}$ Throughout the early Cold War, British policy-makers viewed the defence of the Middle 
East as subordinate only to the defence of Europe and Britain itself. ${ }^{43}$ Eden saw the Middle East as more pressing than relations with the Soviet Union. During his 1953 visit to Washington, knowing that Stalin suffered a stroke, Eden met Dulles and had a "general discussion of everything, especially Egypt (Russia hardly mentioned)". ${ }^{44}$ After learning of Stalin's death, Eden "met [Under Secretary of State Walter] Bedell Smith ... and spent about an hour and a half on various topics, principally Egypt". 45 The Soviet Union did not even represent Britain's greatest concern regionally - President Gamel Abdel Nasser of Egypt troubled the British first and foremost. ${ }^{46}$

Britain pursued a simple set of goals for discussions on the Middle East with the Soviets: to secure in the final communiqué a guarantee of better future behaviour and a promise not to veto the United Nations (UN) Security Council's identification of an aggressor in case of a flare-up in the ArabIsraeli conflict. The flow of Soviet weapons into the region worried British policy-makers, who hoped to stress to the Soviets that such action could precipitate a war on Israel's borders. ${ }^{47}$ The Foreign Office deemed the Middle East "ripe for communism", and with its considerable oil supplies, "the prize ... almost as great" as establishing a sympathetic communist regime as in Europe. Furthermore, the Foreign Office acknowledged that British "weakness [was] correspondingly great" because of divergent policies with the Americans and an obligation to support Israel. ${ }^{48}$ The Foreign Office accurately assessed Russian objectives in the Middle East: to create maximum disturbance without starting a war. ${ }^{49}$

Eden and the Foreign Office hoped discussions with the Soviets would lead to a breakthrough regarding the Arab-Israeli dispute, and that movement on the Middle East would offset any other failures on Britain's part to achieve its goals for breakthroughs during the visit. ${ }^{50}$ This breakthrough did not come, as Khrushchev refused to pledge not to veto a Security Council declaration of an aggressor in case of an eruption of hostilities. ${ }^{51} \mathrm{~A}$ man as preoccupied with prestige as Khrushchev naturally viewed renouncing the right to veto as anathema - here, Britain's poor intelligence regarding Khrushchev hamstrung their negotiating position. Worse still, Khrushchev threatened that "if fighting started, the Arabs might get the help of volunteers skilled in the use of modern weapons". Remembering Chinese "volunteers" in the Korean War, the British feared Soviet pilots being made available to Arab air forces. ${ }^{52}$ Furthermore, Khrushchev had identified himself personally with Soviet support for Nasser's Egypt during the struggle for power in the Kremlin, especially through the provision of Czechoslovak arms. He could ill afford to show a waning commitment to the Soviet Union's best hope for an ally in the Middle East. ${ }^{53}$

In negotiations, whilst Khrushchev and Bulganin "showed an understanding of [British] interests" in the region, especially regarding oil, these assurances did not constitute real progress towards a resolution of the region's tumult. ${ }^{54}$ The final communiqué pledged support for the UN "in 
its endeavour to strengthen peace in the region". 55 Eden told the public that improvement had occurred: the UK and USSR stood "ready to back any United Nations initiative to bring about a permanent peace". ${ }^{6}$ Such lip service to international institutions fell significantly short of Britain's desired outcome. As one participant put it, the Soviets "arrived in a mood of blatant confidence and told us very frankly that whilst in every other part of the world there would be not conflict they would make as much trouble for us in the Middle East as they possibly could. They were as good as their word". 57 When Khrushchev and Bulganin returned to Moscow, they expressed concern over future British actions in the Middle East and planned to warn Nasser of the probable danger posed by British activities. ${ }^{58}$ Khrushchev chafed at the British insisting on "a deal in the sense that everything would be agreed to from their point of view". 59

British policy-makers did not prepare new ideas for negotiations on Germany. Instead, they offered a slight revision of the 1954 Eden Plan, which entailed a demilitarised East Germany within a reunited pro-Western Germany, all-German elections, and strict arms control within 150 miles of the easternmost border of the - soon to be former - Soviet zone. ${ }^{60}$ The United States and Soviet Union had both flatly rejected Eden's plan beforehand. ${ }^{61}$ The British hoped that Khrushchev's recent condemnation of Stalin at the Twentieth CPSU Party Congress would include a repudiation of the former leader's German policies and allow for open discussions on the subject. ${ }^{62}$ Presenting an out-dated proposal constituted a clear error. The British sought to prevent the Soviets from entering into negotiations with an inflexible, pre-formulated platform and, then, proceeded to do just that regarding Germany. ${ }^{63}$

By again presenting the Eden Plan, Britain also demonstrated its failure to appreciate the cultural elements of the Soviets' German policy. In the aftermath of the Second World War, the spectre of German militarism preoccupied the Kremlin. ${ }^{64}$ During the visit, Bulganin told Lloyd that Soviet leaders could not understand why London wanted to rearm the Germans after the atrocities of the Second World War." "If any Soviet government was to allow a united Germany to arm herself", Bulganin declared, it "would be driven out by the Soviet people". ${ }^{6}$ The Soviets had opposed the introduction of West Germany into NATO since its inclusion paved the way for a recrudescence of German militarism. ${ }^{67}$ Britain's miscalculation on this matter is even more surprising given that Eden shared Bulganin and Khrushchev's outlook, affirming that the British people "had little reason to feel tenderly to the Germans after the experience of two world wars". ${ }^{6}$

The British knew that they needed to improve their understanding of the new Soviet doctrine of "peaceful co-existence". Specifically, did Khrushchev's "Secret Speech" at the Twentieth CPSU Congress indicate a change in Soviet attitudes towards expansion and control over satellite states? ${ }^{69}$ British diplomats and politicians hoped for real progress on the issue of disarmament 
in light of Moscow's new tone, but they did not know whether the Soviets would discuss the topic willingly. ${ }^{70}$ On disarmament, the acknowledged limitations of British understanding of the Soviet Union and its policies hampered negotiations from the outset.

The British would only discuss disarmament with two important caveats. First, since Britain needed time to develop and build a stockpile of nuclear weapons before any further prohibition on production, the Ministry of Defence decided against immediate discussions on nuclear disarmament. ${ }^{71}$ Second, the Foreign Office feared that too much progress could anger Britain's NATO allies, whilst also encouraging them to enter into similar bilateral negotiations that could compromise the exclusivity of Britain's planned diplomatic niche as a Cold War intermediary. ${ }^{72}$ The Italian government, for example, seriously feared that the Soviet visit to Britain would lead to an agreement that would satisfy American security concerns in Europe, contributing to the end of American involvement on the continent and a commensurate rise in the influence of Western European communist parties. ${ }^{73}$ Viewing the entire visit with a great deal of scepticism, American policymakers doubted that any such major accord would be struck and did not fear that "Eden is getting ready to don the mantle of Neville Chamberlain in appeasing the Soviet Union". ${ }^{74}$ More to the point, the Soviet Union had no interest in Eden doing so. Ultimately, the two nations pledged little more than to "continue their efforts" at affecting disarmament. ${ }^{75}$

Thus, Britain failed to make significant progress on any of the three key issues identified for negotiations with the Soviets. Its desire to secure a breakthrough on core international issues even prevented smaller-scale successes that reflected Soviet objectives for the visit. The British had drafted a bilateral agreement on cultural contacts and tourism, which prior to the visit the Soviets accepted with only minor adjustments. ${ }^{76}$ At the outset of the visit, Khrushchev indicated his readiness to begin significant exchanges, demonstrating his confidence about settling questions of cultural contacts during the visit - unlike areas of bilateral and international tension. Such agreements would achieve precisely the Anglo-Soviet exchanges that both sides hoped to secure. This expectation did not come to fruition. The two sides' inability to agree blocked progress over reducing broadcasting restrictions - for example, on whether it constituted "interference to demand that broadcasts should not be interfered with" in the context of a dispute over Soviet rhetorical attacks against Britain. ${ }^{77}$

Trade relations fared even worse. The Soviets made clear their intention to purchase goods worth some £1 billion should British strategic controls be relaxed. For Eden, only progress in negotiations regarding the Middle East and the German question would dictate an improvement in trade relations; and in his mind, the two parties made insufficient progress to warrant relaxing these restrictions. ${ }^{78}$ Despite a mutual desire to increase Anglo-Soviet contacts, even these efforts to secure economic and cultural exchanges saw 
only small advances. These types of agreements on lower-level trade, communications, and exchanges did not require significant concessions from either side. Thus, for example, plans for Eden and Macmillan to make a reciprocal visit in April 1957 constituted one of the largest successes in the amelioration of Anglo-Soviet relations in April 1956. ${ }^{79}$

In general, discussions amongst Khrushchev, Eden, and their subordinates unfolded amicably with neither misunderstandings nor grandstanding. ${ }^{80}$ Indeed, the greatest acrimony during the visit took place not at the negotiating table but at a dinner hosted by the opposition Labour Party. Labour naturally desired to meet a potential diplomatic partner should they unseat the Conservatives, something in which the Foreign Office grudgingly acquiesced. After dinner in the House of Commons, the audience began chanting, "we want Khrushchev", who obliged them with a lengthy, offthe-cuff discourse on Britain's role in precipitating the Second World War. Heckling on the subject of the 1939 Molotov-Ribbentrop Pact resulted in an angry tirade from Khrushchev on the uselessness of democratic socialists, which lasted until he stormed out. ${ }^{81}$ When Hugh Gaitskell, the Labour Party leader, called on Khrushchev the next morning to make amends, Khrushchev rebuffed him. ${ }^{82}$ Khrushchev furthermore devoted one-half of his public address after returning to the Soviet Union to attacking the "vile, reactionary, pernicious, provocative, [and] shameless" opposition party. ${ }^{83}$ The Labour dinner illustrates the volatility of the state visit as a diplomatic tool, one that the Foreign Office wielded clumsily in April $1956 .{ }^{84}$

In hosting the Soviet delegation, Britain had the opportunity to gather intelligence. Eden showed little interest in pursuing these opportunities, rejecting numerous proposals during preparations for the visit. Individual agencies continued their efforts, either ignorant of Eden's instructions or disregarding them. These piecemeal efforts yielded minimal information and nearly triggered a major diplomatic incident. Operation Claret, an attempt to gather information about the acoustic characteristics of the recently launched Soviet cruiser, Ordzhonikidze, which transported Khrushchev and Bulganin to Britain, precipitated the so-called Commander Crabb Affair. Spotted by a Soviet sailor, Commander Lionel "Buster" Crabb suffered a fatal equipment failure in the direct vicinity of the vessel. Forbidden by Eden, the operation took place nonetheless. ${ }^{85}$ The British government disavowed any knowledge of Crabb's activities - and the Soviets made little of the embarrassing episode, partly because they accepted such acts of espionage as integral to the Cold War. ${ }^{86}$ Furthermore, they hoped to avoid accusations of needlessly negating diplomatic progress. ${ }^{87}$

Finally, hosting the Soviets offered an opportunity to showcase Britain, a core objective defined by the Foreign Office throughout planning for the visit. The British worked to emphasise two key elements: the nation's military strength and the benefits of consumer-oriented capitalism. Eden directed that the Soviets tour a military installation to see first-hand that 
whilst inferior in terms of population, Britain possessed qualitative technological advances that outweighed or at least balanced Soviet quantitative superiority. At the Harwell Atomic Energy Research Establishment to learn of Britain's allegedly expansive atomic capabilities, the Soviet leaders were not so easily impressed. ${ }^{88}$ They seized on these moments to mention frequently the superiority of Soviet equivalents to what they saw in Britain. ${ }^{89}$

British policy-makers acknowledged the slim chance of effecting significant change in Khrushchev's or Bulganin's fundamental opinion of Britain. Their subordinates, hopefully, would be more open to influence, which proved to be the case. Whilst Khrushchev derided Britain's allegedly obsolete aircraft, his subordinates approached British aviators with questions about their superior equipment. ${ }^{90}$ Soviet aerospace engineer Andrei Tupolev, probably the only member of Khrushchev's entourage equipped to understand what he saw, expressed considerable interest in British atomic achievements on display at Harwell. ${ }^{91}$ Throughout the visit, Khrushchev's son and Tupolev's daughter expressed their excitement. ${ }^{92}$ The British also highlighted the modernity of life in Britain, chiefly to the crew of the Ordzhonikidze taken on tours of London and its shops. ${ }^{93}$ The abundance and variety of British consumer goods did not fail to impress all Soviet visitors. ${ }^{94}$ In this respect, Britain clearly succeeded. The Soviets planned to make a film of their visit that would reach the Russian population at large. ${ }^{95}$ The final film shown in the Soviet Union painted an attractive picture of Britain, neglecting the low-points of the visit and, much to British pleasure, barely mentioning the United States. ${ }^{96}$

During the Soviet visit, Eden confided immodestly to a friend that only the feeling that he might help "to save the world from final catastrophe" kept him in politics. ${ }^{97}$ His performance in negotiations with the Soviet leaders, though the negotiations played out reasonably amicably, fell far short of this hubristic goal. Although agreements were limited, the Khrushchev-Bulganin visit left a warm afterglow in the corridors of power in London. Eden happily informed his Cabinet: "the visit of the Soviet leaders had given rise to fewer embarrassments than he had feared" and that great progress occurred in better understanding the "considerations underlying the views and policies" of the Soviet Union. ${ }^{98}$ In Britain, public opinion no longer considered co-operation and negotiation with the Soviets to be a politically poisonous move, tinged with the spectre of appeasement. Eden bemoaned that support for direct negotiations with the Soviets rose to the point that one official "whom [he] had to order to meet the Russians", was "now tumbling over himself to get to Moscow!" "Even the Queen in a letter to Eden applauded the fact that "our country is beginning to see the possibility of some brightening in the international sky". ${ }^{100}$ Privately, however, Eden directed that British activities abroad that might cause trouble for the Soviets be identified but not halted. ${ }^{101}$ Publicly, he cautioned a television audience that "it doesn't add up, the whole of it, to a revolutionary agreement", but it could be "the beginning 
of a beginning". ${ }^{102}$ Nonetheless, such sentiments fell considerably short of the identified objectives for the visit. In the Kremlin, at the first Presidium meeting following their return, Khrushchev and Bulganin presented an subdued account of their trip, especially when contrasted with the enthusiasm with which they announced the invitation. Commenting in general that the British attempted to overwhelm their visitors with "trivia", Khrushchev spoke complimentarily in diplomatic circles of the Eden government, but this success would be short-lived. ${ }^{103}$

British negotiators - Eden primarily - correctly felt that they had succeeded in building a rapport with the Soviets. ${ }^{104}$ Persuading Britain's NATO allies, especially the United States, of the exclusivity of the little progress made - and generating complementary influence - proved an impossible task. Britain's role internationally was changing. Macmillan compared the new international roles of the British and Americans thus: "we are the Greeks of the Hellenistic age: the power has passed from us to Rome's equivalent . . . and we can at most aspire to civilize and occasionally to influence them". ${ }^{105}$ In keeping with this view, the Foreign Office recalled a Soviet specialist at their Washington Embassy for the visit because not only direct contact with the Soviet leaders would be of considerable value for his duties, but also because policy-makers hoped that this would increase his stature with his State Department counterparts. This step towards establishing Britain's bona fides as a Cold War intermediary bore no fruit. ${ }^{106}$

In their efforts to develop a Cold War role as an intermediary between the United States and the Soviet Union, the British faced two obstacles. They saw Dulles, who held an intransigently negative view of British aspirations to equality with the United States through diplomacy, as their first obstacle. ${ }^{107}$ He derided British efforts to create such a niche, particularly in Middle Eastern affairs, as "desperately grasping at straws to find something that will restore their prestige and influence in the world". ${ }^{108}$ Thus, when presented by the British ambassador at Washington, Sir Roger Makins, with a rather exaggerated report on British achievements in negotiations with the Soviets, Dulles remained nonplussed. ${ }^{109}$ American observers saw the meeting's results as "meager". To them, the Soviet pledge to support UN efforts to bring about peace in the Middle East, which scarcely amounted to a breakthrough, constituted the most important outcome of the visit. ${ }^{110}$ Second, Britain lacked a nuclear capability. An increased reliance on nuclear weapons constituted the core of President Dwight Eisenhower's Cold War strategy, with the threat of "massive retaliatory power" serving as the core deterrent to Soviet aggression. ${ }^{111}$ In this atmosphere, American policy-makers saw British negotiations with the Soviet Union as motivated more by self-preservation than a serious effort or ability to make headway on Cold War issues. ${ }^{112}$ Still lacking a domestic nuclear capability, Britain would need to develop one to exert any meaningful influence on the Eisenhower Administration. ${ }^{113}$ Early in Eisenhower's term, a British "Global Strategy Paper" exerted considerable 
influence over the formulation of Eisenhower's "New Look" national security policy. ${ }^{114}$ The "Global Strategy Paper" had something to offer the Americans in 1953; by comparison, the limited success of the Soviet visit in 1956 gave Britain little leverage in Washington.

The limited improvement in Anglo-Soviet relations was, as Hayter later recorded, "swept away by the terrible events which followed in Eastern Europe and the Middle East" because of the Suez Crisis and the Soviet crackdown in Hungary. ${ }^{115}$ Hayter's successor in Moscow, Sir Patrick Reilly, concurred about the squandering of goodwill generated during the visit as any impression the Soviets had formed of Britain's strength dissipated. ${ }^{116}$ The way in which the Soviet Union expressed its displeasure - nuclear sabrerattling - made clear that Suez annulled any goodwill generated in London. Bulganin asked Eden, "in what position would Britain have found herself had it been attacked by more powerful states possessing all types of modern weapons of destruction?" He declared the Soviet Union "full of determination to crush the aggressor and reestablish peace in the East by using force". ${ }^{117}$ These were not the words of a new partner in peaceful co-existence.

Conventionally, the Suez Crisis constitutes the definitive Cold War turning point in British influence. In April 1956, both through direct Anglo-Soviet negotiations and British attempts to parlay the meetings in London into influence as a Cold War intermediary, the same trends manifested themselves. British foreign-policy makers approached the Soviet visit with the same naïveté. They expected American support for their efforts to carve a diplomatic niche as a privileged go-between for the two superpowers because of their relationship with the United States - the storied "special relationship" and planned breakthroughs with the Soviet Union in April 1956. The events surrounding the Soviet visit, as with the Suez Crisis, indicate that Britain's standing on the world stage had already clearly declined, and that Suez was more a death knell than a turning point. American policy-makers had already made it clear regarding the Soviet visit that they did not want their British counterparts meddling in issues of Cold War concern.

As a case study, the Soviet visit has value within the broader Cold War context, particularly amongst other attempts to ameliorate relations with the Soviet Union. The most direct corollary to Khrushchev's April 1956 trip is his most celebrated visit abroad: to the United States in September 1959. First, however, the April 1956 visit provides a vital point of comparison for Macmillan's trip to Moscow as prime minister in February 1959. He arrived in Moscow feeling "encouraged to act as an arbiter between East and West in the cause of détente", even more so after the onset of Dulles being struck by cancer. ${ }^{118}$ Whilst Macmillan touted the Americans' "complete confidence" in his mission, Washington insisted that in Moscow, Macmillan spoke only for Britain. Macmillan sought the same end as Eden in 1956: to carve for Britain a diplomatic niche. The visit itself unfolded poorly. Khrushchev took extreme umbrage at Macmillan's cautioning against nuclear brinksmanship of 
the kind employed during the Suez Crisis and cancelled public appearances with the British premier. Yet again, a poor understanding of Khrushchev's personality hampered negotiations, as Macmillan under-estimated the extent to which pride and prestige motivated Khrushchev's actions. Though the tone improved over the course of the visit, the two sides again fell short of real progress. ${ }^{119}$ Ultimately, both the Americans and Soviets perceived the trip as petty electioneering on Macmillan's part. ${ }^{120}$ Khrushchev's momentous visit to the United States in September 1959 historiographically dwarfs the 1956 visit. John Lewis Gaddis credits this visit with legitimising direct top-level negotiations as a means of "dealing with Moscow". ${ }^{121}$ A 27 September 1959 Washington Post editorial opined, "the chief accomplishment of the Eisenhower-Khrushchev talks is to open ... East-West negotiations". On learning of Eisenhower's invitation, even Macmillan predicted that in the future, this visit would be seen as a turning point in East-West relations. ${ }^{122}$ Both at the time and historiographically, Britain simply did not factor into Cold War strategy the way Eden and Macmillan hoped. To do so, Eden and Macmillan needed the Eisenhower Administration to acquiesce to Britain's continued role as a Great Power, which was not forthcoming.

The Khrushchev-Eisenhower talks encountered many of the same obstacles that beset negotiations between Khrushchev and Eden three years earlier. In 1956, the host government's preparations focused on the crisis of the moment, the Middle East, at the expense of other possible issues. Similarly, the Eisenhower Administration focused its preparations on a singular issue: the second Berlin Crisis. Even during discussions on other topics, Eisenhower refused to move forward until the two sides made progress regarding Berlin. ${ }^{123}$ This echoed Eden's intransigence and single-minded focus on the Middle East. Had American policy makers analyzed the reasons behind Britain's minimal success in 1956, they would have seen the potential dangers inherent in predicating willingness to negotiate on a range of issues on progress regarding one issue, especially when dealing with an interlocutor like Khrushchev.

What key factors prevented Britain from making any major breakthroughs? First, an almost complete failure to understand the Soviets hampered negotiations. Regarding Germany in particular, Britain failed to appreciate the acute Soviet cultural opposition to German rearmament. Regarding disarmament, it was, ironically, the failure to recognise the similarities between British and Soviet policies. Whilst failure to understand the Soviet position made Britain's goal of creating a diplomatic niche for itself difficult to attain, its over-estimation of its stature within the Western alliance led London to pursue an already unattainable goal.

Compounding Britain's poor understanding of Soviet positions and Western perceptions, its planning for the visit prevented potential breakthroughs. First, the British pursued negotiation on international issues, 
despite their admittedly limited understanding of Soviet policy after Stalin. Furthermore, they made the grave mistake of presenting identical arguments to those previously proposed and rejected. This made the negotiations, in Khrushchev's words, "a case of pouring from one empty vessel into another. Our positions had been made clear even before the meeting in Geneva, so these talks could really add nothing new". ${ }^{124}$ Better planning might have avoided this problem. The British developed fixed positions rather than starting points for the negotiations, whilst attempting to prevent their Soviet counterparts from doing the same, which bore minimal fruit. This inflexibility made achieving Britain's dual goals - concrete breakthroughs on international issues and an increased understanding of the Soviet Union - impossible. The rigid set of discussion topics meant that Eden and Khrushchev often debated previously discussed issues, limiting the opportunity for Britain to gain additional insight regarding Soviet policy positions and motivations.

Finding missed opportunities in the Cold War for superpower rapprochement is all too easy for the historian with access to documents and memoirs that often provide insights about one party which the other could not have hoped to gain at the time. Though some evidence exists that Stalin's death could have been accelerated the process of détente, testing in situ is impossible and thus must remain speculative. ${ }^{125}$ When Khrushchev and Bulganin visited Britain in April 1956, three opportunities for relaxing Cold War tensions confronted the Eden government. None amounted to a phase of détente akin to Eden's naïve and hubristic aspirations, but both individually and together they would have constituted significant steps in that direction. First, British leaders had an opportunity to better understand the new Kremlin leaders' worldview, especially regarding the Middle East, Germany, and disarmament, and to reach limited agreements on those problematic issues, albeit not the sweeping diplomatic breakthroughs for which Eden hoped. Second, Britain's foreign policy apparatus gained a significant opportunity to learn in-depth about the new Soviet regime in a less controlled environment than previous summits at Geneva. British intelligence-gathering efforts bore no fruit and, in the case of the Crabb fiasco, caused significant embarrassment. During the visit, only answers to basic questions regarding the nature of the new Soviet regime emerged, and British policy-makers did not develop the deep understanding of their Soviet counterparts necessary for détente to flourish. Third, the visit offered a clear chance to cultivate trade and cultural contacts between the Eastern and Western blocs. In the short run, increased Anglo-Soviet contact did emerge, but the limited nature of this success made it more easily nullified. Perhaps, with more vested interest in the contacts cultivated by the visit, the dual crises of autumn 1956 in Egypt and Hungary would have soured Anglo-Soviet relations less.

In these three areas, some progress was possible, albeit not of the spectacular nature hoped for by Eden. His hubris played a major role in causing 
the 1956 Soviet visit to be a missed opportunity. Had the British government approached the negotiations with greater flexibility and focused its attention on more attainable goals befitting a first Soviet post-Stalin foreign trip - especially one to a second-tier Power - it would have been prepared to engage with the Soviets in areas in which both sides sought to make progress. This lay in opposition to chasing the ghosts of Britain's historic role as a global power broker.

The 1956 Soviet visit was a microcosmic illustration of Britain's attitude towards the international situation and its role therein. Eden and his government clearly perceived Britain as a major player in the Cold War, and that they acted in Britain's national interest. British leaders saw active diplomacy as a means of counter-acting the process of British decline that had become increasingly palpable in the 1950s. British policy-makers based their diplomatic initiatives upon a genuine faith that Britain could succeed where others had failed. Certainly, Eden could find evidence to foster this hope in his own past diplomatic successes. ${ }^{126}$ Whereas he earlier had accepted the notion that Britain would have to co-operate with the United States internationally, his experience of international politics led him to indulge in self-deception as to Britain's capacity to pursue an independent foreign policy. Events would prove the unattainability of this goal even for him. ${ }^{127}$ Ultimately, this deception and the inflexible and ill-conceived approach to the visit that stemmed from it contributed decisively to the failures of the April 1956 visit.

\section{NOTES}

I wish to thank Arne Hofmann, Jeremi Suri, Mark Kramer, Piers Ludlow, Timothy Naftali, Susan Colbourn, and the anonymous reviewers of Diplomacy \& Statecraft for their comments and suggestions. The remaining shortcomings are mine alone.

1. David Devereaux, The Formulation of British Defence Policy Towards the Middle East, 1948 1956 (London, 1990), p. 193; Saki Dockrill, Eisenhower's New-Look National Security Policy, 1953-1961 (New York, 1996), p. 150; Alistair Horne, Macmillan, Volume 1: 1894-1956 (New York, 1989), p. 359.

2. Mark B. Smith, "Peaceful Coexistence at All Costs: Cold War Exchanges Between Britain and the Soviet Union in 1956", Cold War History, 12(2012), p. 537.

3. Anthony Eden, Full Circle: The Memoirs of the Right Honourable Sir Anthony Eden (London, 1960), p. 12.

4. 1953 Foreign Ministers' Meeting brief, PREM (Prime Minister's Office Papers, National Archives, Kew) $11 / 420$.

5. Klaus Larres, Churchill's Cold War: The Politics of Personal Diplomacy (New Haven, CT, 2002), p. 189.

6. Hayter to Macmillan, 6 June 1955, PREM 11/1015.

7. Larres, Churchill's Cold War, pp. 193-96.

8. Ward memorandum, 30 March 1955, FO (Foreign Office Papers, National Archives, Kew) $371 / 116674$ $11 / 1624$

9. Macmillan to Eden, 8 August 1955, PREM 11/897; Eden to Simonds, 20 July 1955, PREM

10. Soviet visit programme draft, 12 August 1955, FO 371/116682; Eden to Hayter, 9 August 1955, PREM 11/1624.

11. "Anglo-Soviet Relations", 3 January 1956, PREM 11/1624. Khrushchev considered the tour of India, Burma, and Afghanistan to have been a resounding success: Presidium meeting record, 
22 December 1955, in Aleksandr Fursenko, ed., Prezidium TsK KPSS, 1954-1964: Chernovye protokol'nye zapisi zasedaniı Stenogrammy, Volume 1 (Moscow, 2003), pp. 72-75.

12. Draft note to USSR, 31 December 1955, FO 371/122809; Cabinet decisions, 6 December 1956, PREM 11/1624.

13. Meeting record, 9 January 1956, FO 371/122809.

14. Cabinet decisions, 11 January 1956, PREM 11/1624.

15. Eden to Salisbury, 4 April 1956, PREM 11/1625.

16. Richard Thorpe, Eden: The Life and Times of Anthony Eden (London, 2003), p. 415.

17. Maitland oral history transcript, 11 December 1997, BDOHP (British Diplomatic Oral History

Programme, Churchill College Archives, Cambridge University, Cambridge) p. 27.

18. William Hayter, A Double Life (London, 1974), p. 127.

19. Hibbert memorandum, 3 October 1955, FO 371/116641.

20. Hayter to Ward, 3 June 1955, FO 371/116640.

21. Moscow to London, 14 May 1955, Ibid.

22. Dwight D. Eisenhower, Mandate for Change, 1953-1956 (Garden City, 1963), p. 521.

23. Richard Bevins and Gregory Quinn, "Blowing Hot and Cold: Anglo-Soviet Relations", in Wolfram Kaiser and Gillian Staerck, ed., British Foreign Policy, 1955-1964: Contracting Options (Basingstoke, 2000), p. 210; "Soviet Visit", PREM 11/1624.

24. Fraser memorandum, 15 July 1955, FO 371/116641.

25. Horne, Macmillan, Volume 1, p. 361.

pp. $174-79$

26. David Cannadine, Ornamentalism: How the British Saw Their Empire (Oxford, 2001),

27. Hayter, Double Life, p. 114.

28. Moscow to London, 26 January 1956, PREM 11/1624.

29. Reading to Eden, 8 February 1956, Ibid.

30. Meeting record, 28 March 1956, PREM 11/1625.

31. Dulles to Eisenhower, 3 April 1956, RG 59 (State Department Archives, National Archives and Records Administration, College Park, MD), 1955-1959 Central Decimal Files, box 2606, folder 641.61/12555 .

32. Maitland to Millard, 21 March 1956, PREM 11/1626.

33. London to Washington, 18 April 1956, PREM 11/1613.

34. Vladislav Zubok and Constantine Pleshnakov, Inside the Kremlin's Cold War: From Stalin to Khrushchev (Cambridge, 1996), pp. 183-187; William Taubman, Khrushchev: The Man, His Era (New York, 2003), pp. 349-350; Svetozar Rajak, Yugoslavia and the Soviet Union in the Early Cold War: Reconciliation, Comradeship, Confrontation, 1953-1957 (Milton Park, 2011), pp. 66-108.

35. Nikita Khrushchev (Sergei Khrushchev, ed.), The Memoirs of Nikita Khrushchev, Volume 3: Statesman, 1953-1964 (University Park, PA, 2007), p. 30.

36. Caccia memorandum, 22 July 1955, FO 371/116675.

37. Khrushchev, Memoirs, Volume 3, pp. 38-42.

38. Andrei Aleksandrov-Agentov, Ot Kollonta do Gorbacheva: Vospominaniia diplomata, sovetnika A.A. Gromyko, i pomoshchnika L.I. Brezhneva, Iu.V. Andropova, K.U. Chernenko i M.S. Gorbacheva (Moscow, 1994), pp. 99-102.

39. Quoted in Peter Mangold, Success and Failure in British Foreign Policy: Evaluating the Record, 1900-2000 (Basingstoke, 2001), p. 128.

40. London to Washington, 18 April 1956, PREM 11/1613; Khrushchev, Memoirs, Volume 3, p. 67.

41. Meeting record, 28 March 1956, PREM 11/1625.

42. Maitland oral history transcript, 11 December 1997, BDOHP 27.

43. Geoffrey Warner, "Anglo-American Relations and the Cold War in 1950", Diplomacy \& Statecraft, 22(2011), pp. 45-46.

44. Eden diary entry, 4 March 1953, AP (Avon Papers, Cadbury Research Library, University of Birmingham, Birmingham) 20/1.

45. Eden diary entry, 9 March 1953, Ibid.

46. Nigel Ashton, Eisenhower, Macmillan, and the Problem of Nasser: Anglo-American Relations and Arab Nationalism, 1955-1959 (Basingstoke, 1996), p. 73.

47. Ward memorandum, 11 April 1956, PREM 11/1626.

48. Maitland to Eden, 18 October 1955, PREM 11/1709.

49. Meeting record, 11 April 1956, PREM 11/1625. 
50. Meeting record, 11 April 1956, Ibid.; Meeting record, 13 April 1956, PREM 11/1626.

51. "Soviet Visit", PREM 11/1624.

52. Keith Kyle, Suez: Britain's End of Empire in the Middle East (London, 2003), p. 105.

53. Naftali and Fursenko, Khrushchev's Cold War, p. 142.

54. Eden, Full Circle, p. 401; "Soviet Visit", PREM 11/1624.

55. "Statement on Discussions", PREM 11/1624.

56. Eden ministerial broadcast transcript, 27 April 1956, AP 12/3/478W.

57. Ivone Kirkpatrick, The Inner Circle (London, 1959), p. 262.

p. 127.

58. Presidium meeting record, 6 November 1955, in Fursenko, Prezidium TsK KPSS, Volume 1

59. Khrushchev, Memoirs, Volume 3, p. 67.

60. Hayter to Ward, 24 February 1956, FO 371/122816.

61. Saki Dockrill, "The Eden Plan and European Security", in Günter Bischoff and Saki Dockrill, eds., Cold War Respite: The Geneva Summit of 1955 (Baton Rouge, LA, 2000), pp. 172-75; Khrushchev, Memoirs, Volume 3, p. 36.

62. Johnson memorandum, 17 April 1956, FO 371/122826.

63. Maitland to Millard, 21 March 1956. PREM 11/1626; Kirkpatrick memorandum, 23 April 1956, FO 371/122827; Khrushchev, Memoirs, Volume 3, p. 67.

64. Anne Deighton, The Impossible Peace: Britain, the Division of Germany and the Origins of the Cold War (Oxford, 1990), p. 95.

65. Conversation record, 21 April 1956, FO 371/122831.

66. "Soviet Visit", PREM 11/1624.

67. Moscow to London, 26 April 1956 FO 371/116670; Presidium meeting record, 7 November 1955, in Fursenko, Prezidium TsK KPSS, Volume 1, p. 60.

68. Eden, Full Circle, p. 333.

69. "Soviet Visit", PREM 11/1624.

70. Nutting memorandum, 10 April 1956, FO 371/123693.

71. Meeting record, 12 April 1956, PREM 11/1625.

72. Foreign Office memorandum, 21 April 1956, FO 371/123694.

73. Rossi-Longhi-Luce memorandum of conversation, 17 April 1956, RG 59, 1955-1959 Central Decimal Files, box 2606, folder 641.61/1-2555.

74. Evans to Armstrong, 19 July 1956, Ibid.; Dillon to Dulles, 5 May 1956, RG 84 (Records of the Foreign Service Posts of the Department of State, National Archives and Records Administration, College Park, MD), Great Britain, 1945-1958 Top Secret General Records, box 4, folder: "320 Western Block 1956".

75. "Statement on Discussions", PREM 11/1624.

76. Meeting Record, 28 March 1956, PREM 11/1625.

77. "Soviet Visit", PREM 11/1624.

78. Meeting record, 12 April 1956, PREM 11/1625; "Statement on Discussions", PREM 11/1624.

79. "Soviet Visit", PREM 11/1624; Smith, "Peaceful Coexistence", p. 553.

80. "Soviet Visit", PREM 11/1624.

81. Hohler minute, 23 January 1956, FO 371/122810; George Brown, In My Way: The Political Memoirs of Lord George-Brown (London, 1971), pp. 71-73.

82. Foreign Office minute, 27 April 1956, PREM 11/1626.

83. Moscow to London, 1 May 1956, FO 371/122830.

84. See a detailed discussion of the state visit as a diplomatic tool in Erik Goldstein, "The Politics of the State Visit", The Hague Journal of Diplomacy, 3(2008), pp. 153-78.

85. Bridges minute, 18 May 1956, PREM 11/2077.

86. Foreign Office to Soviet Embassy, 9 May 1956, AP 12/3/491.

87. Khrushchev, Memoirs, Volume 3, p. 83.

88. Foreign Office minute, 16 February 1956, PREM 11/1624; Cockcroft to Jackson, 6 March 1956, AB (UK Atomic Energy Authority Papers, National Archives, Kew) 6/1874.

89. Hayter minute, 2 May 1956, FO 371/122834.

90. "Soviet Visit: Interpreters' Notes", PREM 11/1624.

91. Ibid.

92. Hayter minute, 2 May 1956, FO 371/122834.

93. Hohler minute, 4 April 1956, FO 371/122823.

94. "Soviet Visit: Interpreters' Notes", PREM 11/1624. 
95. Moscow to London, 17 February 1956, PREM 11/1625.

96. Clark to de Zulueta, 24 August 1956, PREM 11/1628.

97. Booth to Eden, 27 April 1956, AP 16/4/37A.

98. Cabinet decisions, 26 April 1956, PREM 11/1626.

99. Eden diary, 25 May 1956, AP 20/1.

100. Quoted in Robert Rhodes James, Anthony Eden (London, 1986), p. 600.

101. Eden to Lloyd, 30 April 1956, AP 20/21/84.

102. Eden, Broadcast transcript, 27 April 1956, AP 12/3/478W.

103. Presidium meeting record, 3 May 1956, in Fursenko, Prezidium TsK KPSS, Volume 1, 126-27.

104. Eden, Full Circle, p. 363; Khrushchev, Memoirs, Volume 3, p. 68.

105. Quoted in Alex Danchev, "On Specialness", Diplomatic History, 72(1996), p. 740.

106. Hohler memorandum, 24 February 1956, FO 371/122815.

107. Evelyn Shuckburgh (John Charmley, ed.) Descent to Suez: Diaries 1951-1956 (London, 1986), p. 19.

108. Quoted in Ashton, Problem of Nasser, p. 79.

109. Dulles memorandum, 30 April 1956, in Foreign Relations of the United States, 1955-1957, Volume 27: Western Europe and Canada (Washington, DC, 1992), pp. 655-56.

110. Matthews to Dulles, 1 May 1956, RG 59, 1955-1959 Central Decimal Files, box 2606, folder 641.61/1-2555.

111. Dockrill, Eisenhower's New-Look, pp. 54-55.

112. Dale to Lister, 1 March 1956, RG 59, 1955-1959 Central Decimal Files, box 2606, folder 641.61/1-2555.

113. John Baylis, "Exchanging Nuclear Secrets: Laying the Foundations of the Anglo-American Relationship", Diplomatic History, 25(2001), p. 38.

114. Andrew M. Johnston, "Mr. Slessor Goes to Washington: The Influence of the British Global Strategy Paper on the Eisenhower New Look", Diplomatic History. 22(1998), pp. 361-62.

115. William Hayter, The Kremlin and The Embassy (London, 1966), p. 139. Smith, "Peaceful Coexistence", p. 545 quotes Hayter's description of the new, warmer tone with which Khrushchev spoke about Britain and the Eden government at length, yet this conclusion on the part of Britain's ambassador is absent, despite concluding the paragraph from which he quotes.

116. Bevins and Quinn, "Blowing Hot and Cold", pp. 214-215.

117. Quoted in Fursenko and Naftali, Khrushchev's Cold War, p. 134.

118. Kathleen Newman, Macmillan, Khrushchev and the Berlin Crisis (London, 2007), p. 63.

119. Taubman, Khrushchev, pp. 410-12.

120. Marc Trachtenberg, A Constructed Peace: The Making of the European Settlement, 1945-1963 (Princeton, NJ, 1999), p. 265.

121. John Lewis Gaddis, Strategies of Containment: A Critical Appraisal of American National Security Policy During the Cold War, $2^{\text {nd }}$ edition (Oxford, 2005), p. 195.

122. Mangold, Success and Failure, p. 134.

123. Eisenhower to Adenauer, 28 September 1959, in Louis Galambos and Daun van Ee, eds., The Papers of Dwight David Eisenhower, Volume 20: Keeping the Peace (Baltimore, MD, 2001), p. 1676.

124. Khrushchev, Memoirs, Volume 3, p. 67.

125. This theme is covered extensively in Klaus Larres and Kenneth Osgood, eds., The Cold War After Stalin's Death: A Missed Opportunity for Peace? (Lanham, MD, 2006).

126. Matthew Grant, Introduction, in idem., ed., The British Way in Cold Warfare: Intelligence, Diplomacy and the Bomb, 1945-1975 (London, 2009), p. 3.

127. Kevin Ruane and James Ellison, "Managing the Americans: Anthony Eden, Harold Macmillan and the Pursuit of 'Power-by-Proxy' in the 1950s", Contemporary British History, 18(2004), p. 155.

Simon Miles is a PhD student in the Department of History and a Fellow at the William P. Clements Jr. Center for History, Strategy and Statecraft at the University of Texas at Austin. His doctoral research project is an examination of Soviet-American relations during the early 1980s with a particular focus on the frequent leadership changes in the Soviet Union during the time period and the Reagan Administration's attempts to understand them. He is a graduate of the University of Toronto (BA, History) and the London School of Economics (MA, International History). 